\title{
Threat Reduction and North Korea's CBW Programs
}

\author{
Elisa D. HARRis
}

$\mathrm{F}$ or most of the past decade, U.S. policy toward North Korea has focused 1 almost exclusively on the threat from Pyongyang's indigenous nuclear weapons and long-range missile programs and on the risk of transfers from those programs to other proliferators. Little attention has been paid to North Korea's purported chemical weapons (CW) and biological weapons (BW) activities, despite the fact that CW or BW could well be used against U.S. and South Korean targets in the event of a war on the Korean Peninsula, and that CW- or BWrelated transfers from North Korea could circumvent the steadily expanding web of export control efforts provided for under the Australia Group, the Chemical Weapons Convention (CWC) and, most recently, UN Security Council resolution 1540. This article examines this neglected aspect of North Korea's military posture, with a view toward outlining how it might be addressed.

The article begins by deconstructing the threat, exploring both the likely nature and extent of Pyongyang's CW and BW activities, as well as the many uncertainties that remain. It then considers how threat reduction programs that have been applied in other countries might be used to help mitigate and, over time, eliminate the North Korean CW and BW problem. The article concludes with a discussion of the lessons that can be learned from these other threat reduction experiences for implementing similar programs in North Korea and other countries.

\section{Deconstructing the Threat}

Determining the threat from foreign $\mathrm{CW}$ and $\mathrm{BW}$ programs has long been recognized as particularly challenging, given that the facilities where the weapons are developed and produced generally have no unique signatures and most of the equipment and materials are dual-use-and thus can have both military and nonmilitary applications. The challenges are even more acute in the case of North 
Threat Reduction and North Korea's CBW Programs

Korea, one of the most politically and economically isolated countries in the world. Nevertheless, over the past decade, several key countries have reached judgments about North Korea's CW and BW activities and have disclosed that information in a range of official statements and reports. Additional information has appeared in unofficial accounts, including news stories and journal articles. ${ }^{1}$ As discussed below, North Korea probably does have both a CW and a BW program, although there are almost certainly important differences between them. Moreover, many uncertainties remain about specific aspects of North Korea's activities in each of these areas.

\section{CW Profile}

U.S., Russian and South Korean government sources have indicated for more than a decade that North Korea has an active chemical weapons program and has produced and stockpiled chemical weapons. According to a 1996 U.S. Defense Department (DOD) report, North Korea began to develop its chemical industry and CW production capability after the Korean War and began to produce CW "experimentally" in the late 1960s. Since the late 1980s, these efforts reportedly have expanded and intensified. ${ }^{2}$ Today, North Korea's chemical industry is believed to be capable of producing a wide variety of traditional $\mathrm{CW}$ agents, including nerve, blister, blood, and choking agents, although both the U.S. Central Intelligence Agency (CIA) and the DOD report that the industry itself is aging. ${ }^{3}$ In 2002, the commander of U.S. Forces in Korea also expressed doubts about North Korea's CW production capability, saying that Pyongyang could produce only "components for first generation" CW, meaning World War I agents, on its own. ${ }^{4}$ If true, North Korea would need to import chemicals and possibly equipment from abroad to produce the more lethal nerve agents. Although U.S. government reports provide little specific information about the composition of North Korea's CW stockpile, both the CIA and State Department have said that Pyongyang is capable of delivering $\mathrm{CW}$ agents in a variety of ways, including by missiles. ${ }^{5}$ U.S. officials have offered varying estimates of the amount of $\mathrm{CW}$ agent in North Korea's stockpile, from "a minimum of 2,500 tons" to "up to 5,000" metric tons. ${ }^{6}$ They have not, however, disclosed specific information about the location of North Korea's CW facilities or of the number of personnel believed to be involved in the program.

The Russian Federal Security Service's (FSB's) 1993 proliferation report corroborated U.S. government claims that North Korea has moved beyond research and development $(R \& D)$ on chemical weapons and has a CW agent production capability embedded within its chemical industry. ${ }^{7}$ It also indirectly addressed the issue of CW stocks by referring to U.S. and South Korean claims that North Korea has stockpiles of "toxic substances" and by noting Pyongyang's failure to sign the CWC. ${ }^{8}$ 
Perhaps not surprisingly, South Korean government sources have gone even further than their Russian and U.S. counterparts in describing key elements of North Korea's CW program, particularly the size of its stockpile and the number and location of the sites involved. Seoul's 2000 Defense White Paper, for example, said that North Korea had a CW stockpile of between 2,500-5,000 tons of lethal chemicals. ${ }^{9}$ The following year's Defense White Paper used the same range for both chemical and biological weapons, while another Ministry of National Defense publication used it for chemical weapons alone. ${ }^{10}$ It is not clear, therefore, whether the South Korean government believes that North Korea has between 2,500-5,000 tons of CW only, or whether these figures are intended to include BW as well. ${ }^{11}$

Over the past 10 years, the South Korean government has also disclosed an increasing amount of information about the number of facilities involved in North Korea's CW program as well as their general location. The 1993-1994 Defense White Paper reported that North Korea had eight CW production sites. ${ }^{12}$ In 1996, the Defense White Paper included a map of North Korea's CW facilities, which marked but did not identify by name eight production, six storage, and three research sites. ${ }^{13}$ By the time of the 2001 Defense White Paper, the number of storage and research facilities had each increased by one. ${ }^{14}$

Unofficial sources, particularly news reports and journal articles, have contained even more detailed information about North Korea's CW program than have South Korean government reports. In 1996, for example, Joseph Bermudez claimed in an article in Jane's Intelligence Review that North Korea was producing a total of 20 different $\mathrm{CW}$ agents and that its stockpile was "reported" to include sarin, soman, tabun, and the V-series nerve agents; the blister agents mustard and phosgene oxime; the blood agent hydrogen cyanide; the choking agent phosgene; and the riot control agents CN, CS, and DM. ${ }^{15}$ The South Korean National Intelligence Service is widely believed to be at least one of Bermudez's sources. Nevertheless, his claim that North Korea had stockpiled nerve agents, especially V-agents, is difficult to reconcile with U.S. government statements regarding the limitations of North Korea's CW production infrastructure. An almost identical list subsequently was included in an article by an official from South Korea's Agency for Defense Development, Pak Tong Sam, in 1999 and in a lengthy article on North Korea's CW and BW programs in the Korean Journal of Defense Analysis in 2002, although by the latter date the agents were said to be "known" to be in Pyongyang's current inventory. ${ }^{16}$

Unofficial sources also have provided some of the earliest estimates of the size of North Korea's CW stockpile, often reportedly based on information from South Korean officials. In 1987, for example, the Korea Herald quoted the Minister of Defense as saying that North Korea had stockpiled some 180-250 tons of CW. ${ }^{17}$ In 1993, Joseph Bermudez claimed in Jane's Intelligence Review that North Korea had stockpiled 1,000 tons of chemical weapons. ${ }^{18}$ By 1999, South Korean 
Threat Reduction and North Korea's CBW Programs

defense official Pak Tong Sam was maintaining that the stockpile was known to contain 2,500-5,000 tons of CW. ${ }^{19}$ North Korean defectors generally have provided worst-case assessments, claiming that the stockpile was 5,000 tons of agent. ${ }^{20}$

Press accounts and journal articles also have been the only source of information about the specific sites said to be involved in North Korea's CW program. Altogether, more than three dozen locations or specific facilities have been identified over the past 20 years. ${ }^{21}$ As with the information on North Korea's CW agents, much of the facility information appeared first in articles by Joseph Bermudez and was then repeated in other articles. Both North Korean defectors and South Korean sources figure prominently in these reports.

\section{BW Profile}

U.S., Russian, and South Korean government sources also agree that North Korea has a biological weapons program, but there is no consensus on whether Pyongyang's BW efforts have gone beyond research and development. Recent U.S. government reports indicate that North Korea has pursued biological weapons since the 1960s but suggest that it has yet to achieve a BW capability. ${ }^{22}$ As with its CW program, North Korea is reported to have dual-use rather than dedicated military facilities that could be used to produce BW agents, although both the State and Defense Departments have noted that this infrastructure is far from mature. ${ }^{23}$ North Korea is also said to possess a munitions production infrastructure that would allow it to weaponize BW agents, but no U.S. government agency has confirmed that Pyongyang actually has done so or that it possesses BW. ${ }^{24}$ U.S. government reports also provide little specific information about the types of agents that might have been weaponized, other than to note North Korea's ability to produce agents like anthrax, plague, cholera, and smallpox..$^{25}$ No mention has been made either of a stockpile size or of specific BW facilities.

As of 1993, the Russian FSB also appeared to believe that North Korea's BW program was still at the R\&D level, with "military-biological research" in a number of institutes and universities and testing on North Korean islands. The FSB also identified anthrax, plague, cholera, and smallpox as the focus of North Korean work, but left open the possibility that the program was for defensive rather than offensive purposes. ${ }^{26}$

South Korean government sources have gone further in their characterization of North Korea's BW program, implying not only that Pyongyang has moved beyond research and development but that it actually possesses biological weapons. Seoul's 1998 and 1999 Defense White Papers reported that by 1980, North Korea had succeeded in developing bacteria and viruses for BW and by the late 1980s had "completed live experiments" with such weapons. ${ }^{27}$ In 2001, the Ministry of National Defense claimed that North Korea possessed one or two types of $\mathrm{BW}$ agents and, as noted above, a stockpile of 2,500-5,000 tons of biological as 
well as chemical weapons. ${ }^{28}$ It also included a map in its Handbook on Weapons of Mass Destruction on which six BW research and three BW production facilities were marked but not identified by name. ${ }^{29}$ Such a map has not appeared in the Defense White Papers, which have simply noted that North Korea is "suspected of maintaining" numerous facilities for "cultivating and producing" BW. ${ }^{30}$

As with North Korea's CW program, unofficial sources such as newspapers and journals have provided the most detailed descriptions of North Korea's BW program. In 1993, for example, a South Korean press article claimed, reportedly based on information from South Korean government sources, that North Korea had produced 13 different types of BW agents. ${ }^{31}$ This is more than either the United States or the former Soviet Union produced in their BW programs. Other news stories out of Seoul since that time have made similar claims. ${ }^{32}$ Many of the specific BW agents said to be in North Korea's inventory have also been named. In 1998, Joseph Bermudez said that the agents reportedly included anthrax, botulism, cholera, hemorrhagic fever, plague, smallpox, typhoid, and yellow fever, although he acknowledged questions about the reliability of this information. ${ }^{33}$ Most of this list was repeated in the Korean Journal of Defense Analysis 2002 article on North Korea's CW and BW programs, but without attribution. ${ }^{34}$ Bermudez and South Korean sources have also identified, together, more than two dozen locations or specific facilities said to be involved in North Korea's BW program. ${ }^{35}$ Most of this information appears to have come from North Korean defectors or sources linked to South Korea's security agencies.

\section{Discussion}

In recent years, the United States and other governments have failed to assess accurately the nature and scope not only of Iraq's CW and BW programs but also those of Libya. Prior to Libya's December 2003 renunciation of weapons of mass destruction, both the United States and Russia believed that Libya had a BW R\&D program, and the United States believed that Libya had constructed three $\mathrm{CW}$ production facilities and had produced at least 100 metric tons of $\mathrm{CW}$ agent. ${ }^{36}$ None of these assessments has proved correct. Given this experience, official pronouncements concerning North Korea's CW and BW programs clearly should be viewed with a degree of caution. As the chairman of the U.S. Joint Chiefs of Staff said in June 2003, "Intelligence doesn't necessarily mean something is true. It's just-it's intelligence. You know, it's your best estimate of the situation. It doesn't mean it's a fact." ${ }^{37}$

As has been shown, the United States, Russia, and South Korea clearly believe that North Korea has both a CW and a BW program. This probably is true, although important differences between the two programs almost certainly exist. North Korea's BW program probably has not progressed much beyond the R\&D 
Threat Reduction and North Korea's CBW Programs

level, with small quantities of BW agent being produced for test and evaluation purposes. Its CW program, by comparison, almost certainly is more advanced, and probably includes at least some production and stockpiling of actual weapons. Many uncertainties remain, however, about the specific $\mathrm{CW}$ agents and munitions in North Korea's CW stockpile; its size; the location of the relevant research, production, and storage facilities; and the number of people involved. Most of the details of North Korea's BW program are even more uncertain. Questions remain about the types of BW agents that may have been developed as well as the facilities and personnel that may have played a role in the program.

As discussed above, unofficial sources, particularly press accounts and journal articles, have provided detailed information on virtually all of these issues. This information should not, however, be considered authoritative. In some cases, the reports are based on information from North Korean defectors, none of whom were directly involved in offensive activities. Others appear to include information that South Korean government agencies were either unwilling or unable to put in official reports, thus raising questions about the motives behind releasing the information through nongovernmental sources. Some repeat information from other unofficial sources, not always with attribution. Finally, some include information that simply can't stand up to scrutiny, thus calling into question the accuracy of other information they contain. In short, much of the detailed information about North Korea's CW and BW programs from unofficial sources needs to be viewed with even greater caution than the claims from official sources.

In the final analysis, the only way of beginning to resolve the many questions that remain about North Korea's CW and BW programs is by access-to the places and people believed to be involved in these activities. Threat reduction programs like those that have been undertaken in the former Soviet Union, Iraq, and Libya clearly can not only facilitate this process but can also help eliminate the threat from these North Korean programs.

\section{Threat Reduction Models}

Both the United States and the international community have had a considerable amount of experience using threat reduction programs to deal with the CW and BW programs of the former Soviet Union, especially Russia. Iraq has also been the focus of threat reduction efforts-by the United Nations following the First Gulf War and, more recently, by the United States since the removal of Saddam Hussein from power. Threat reduction plans are also being developed for Libya, now that it has agreed to forgo weapons of mass destruction. These countries differ in a number of ways-historically, culturally, and economically. Two differences, however, are particularly important to this discussion.

The first concerns the scale of their weapons programs. The former Soviet Union had the world's largest and most advanced CW and BW programs. The 
Soviet BW program involved more than 50 military and nonmilitary scientific institutes and employed upwards of 60,000 scientists, technicians, and support personnel. Many of the sites contained large collections of dangerous pathogens and infrastructure that could be used for industrial-scale production of biological agents. The Soviet CW program resulted in a declared stockpile of 40,000 metric tons of nerve and blister agent developed and produced in more than two dozen facilities in Russia and other parts of the former Soviet Union.

Libya is at the other end of the weapons capability spectrum. In its initial declaration to the Organization for the Prohibition of Chemical Weapons (OPCW) following its accession to the CWC in February 2004, Libya revealed that it possessed 3,563 unfilled chemical bombs, 23 metric tons of bulk mustard agent, two chemical storage facilities, one CW production facility, and more than 1,300 metric tons of precursor chemicals. ${ }^{38}$ Libya has denied that it ever had a BW program, although it has acknowledged past intentions to acquire equipment and develop capabilities related to biological weapons. ${ }^{39}$ Little is known about the size of the scientific and technical community that supported the Libyan CW program and that could have been used in an active BW effort.

In between is Iraq, which had the largest and most advanced CW and BW programs in the developing world. Following the First Gulf War, Iraq declared that it had produced some 3,859 tons of mustard and nerve agents and more than 200,000 filled and unfilled munitions, much of which was expended in the 1980s during the Iran-Iraq War. Over 20,000 tons of precursor chemicals were also procured or produced for $\mathrm{CW}$ use. The Muthanna $\mathrm{CW}$ production facility and Fallujah precursor plants were central to these efforts. ${ }^{40}$ Between 1985 and 1990, Iraq's BW program progressed from basic research to the production of thousands of liters of bacterial and toxin agents. Much of this work occurred at the Al-Hakam BW production facility, although other sites also played a role in the Iraqi BW program..$^{41}$

A second important difference between the three countries concerns the political context in which CW and BW threat reduction efforts have been carried out. In Russia, threat reduction was designed, at least initially, to help eliminate the threat from the former Soviet CW and BW programs by assisting Russia in meeting its arms control obligations. In 1992, in order to secure Russia's signature of the CWC, the United States agreed to help Moscow destroy its CW stockpile. Shortly thereafter, in an effort to obtain greater transparency at former Soviet BW institutes, the United States began to fund a small number of collaborative research projects with former Soviet BW scientists. Over the following decade, these programs grew to include the dismantlement of former $\mathrm{CW}$ and BW facilities as well as enhanced security arrangements for chemical and biological weapons-related material. This expansion in the scope of the threat reduction programs was stimulated, at least in part, by growing concerns about the possible proliferation of CW and BW capabilities from the former Soviet programs to other nations or subnational groups. 
Threat Reduction and North Korea's CBW Programs

Given this background, Russia, and especially the Russian military, was often at best ambivalent about cooperating with the United States and other countries to eliminate the $\mathrm{CW}$ and $\mathrm{BW}$ programs in which it had invested so heavily during the Cold War. U.S. questions about the size and composition of the Russian CW stockpile and the facilities where it was developed, and about the scope of the former Soviet BW program-especially the role of the military institutes in BW development and production-were never adequately answered. Political and financial support for CW- and BW-related disarmament was never a Russian government priority. These factors, in turn, have complicated efforts to secure political support within the United States for funding CW and BW threat reduction programs in Russia.

The political context for threat reduction efforts in Libya is very different. Libya's December 2003 announcement that it was abandoning its much more limited weapons of mass destruction programs was the culmination of a decadelong effort to trade its proliferation and terrorism activities for more normal relations with the West, especially the United States ${ }^{42}$ Although there were no specific discussions about lifting sanctions or other benefits, U.S. officials made clear before the December announcement that the elimination of Libya's weapons programs would not go unrewarded. ${ }^{43}$ In February 2004, the United States ended passport and travel restrictions to Libya, opened a U.S. interest section in Tripoli, and allowed U.S. companies to begin to renegotiate contracts with Libya. Two months later, the United States cleared the way for further commercial and financial transactions by lifting the presidentially imposed sanctions under existing executive orders and the Iran-Libya Sanctions Act. ${ }^{44}$ Libya still needs to be removed, however, from the terrorism list. This is particularly important, as Libya cannot qualify for most U.S. assistance programs as long as it remains on the terrorism list. The overall political context for threat reduction efforts with Libya is thus highly conducive to cooperation.

The same could not be said for Iraq, at least following the First Gulf War. For nearly eight years Iraq tried to deceive inspectors from the UN Special Commission (UNSCOM) about the nature, scope, and location of its prohibited weapons activities. After its withdrawal from Iraq in December 1998, UNSCOM reported to the UN that it had been unable to account for more than 6,500 chemical artillery shells and bombs, at least 1.5 tons of the nerve agent VX, about 100 biological bombs, over 30,000 liters of concentrated biological agent, at least 2,100 tons of biological growth media, and some 1,800 tons of chemical precursors. ${ }^{45}$

Iraq's refusal to cooperate with the UN-imposed disarmament regime complicated efforts to root out and eliminate every aspect of Iraq's CW and BW programs. It now seems clear, however, that Iraq's ability to launch militarily significant attacks with chemical and biological weapons was severely degraded by UNSCOM's threat reduction activities in the 1990s. Now that Saddam Hussein has been removed from power, a more cooperative political environment hope- 
fully exists to address the last vestiges of Iraq's CW and BW programs: the scientists and other experts who implemented the programs.

North Korea is unlikely to conform exactly to any one of these models. As discussed above, there are considerable uncertainties about the nature and extent of North Korea's CW and BW programs. The most authoritative information currently available suggests that its $\mathrm{CW}$ program may be similar to that of Iraq's, although with more facilities potentially involved. Its BW activities may well go beyond those of Libya but fall short of the more advanced Iraqi program. Even more uncertain is the political context in which CW and BW threat reduction efforts in North Korea might be carried out. North Korea could follow the Russian model and agree, somewhat reluctantly, to work with the United States and other countries to meet its existing obligations to the Biological and Toxin Weapons Convention (BTWC) and to join and comply with the CWC. It could also follow the Libyan or post-Saddam Iraqi model and renounce $\mathrm{CW}$ and BW either as part of a comprehensive agreement or in the aftermath of a change in regime. Probably the least likely scenario is one in which North Korea's weapons activities are the target of UN-imposed disarmament efforts, as was the case with Iraq following the First Gulf War. Whether North Korea would be more or less inclined to forgo its $\mathrm{CW}$ and $\mathrm{BW}$ programs, as compared to its nuclear and missile programs, is also an open question.

\section{Threat Reduction in Practice}

Given that CW and BW threat reduction in North Korea is likely to combine elements of each of the three models discussed above, it is worth looking at the actual experience with threat reduction activities in these countries to see what might be relevant. Each of the four key elements of a weapons capability - weapons, infrastructure, material and personnel—is considered below.

\section{Weapons}

Eliminating chemical and biological weapons should not, at least in principle, pose significant political or technical problems. Both CW and BW have been outlawed by international treaties whose provisions, unlike the Treaty on the Non-Proliferation of Nuclear Weapons, apply uniformly to all member states. Today, 167 countries are parties to the CWC, and 153 to the BTWC. Moreover, the United States and a number of other countries have had considerable experience destroying CW and BW safely. Nevertheless, the actual experience with weapons dismantlement in Russia, Iraq, and Libya has varied considerably.

More than a decade after the United States first agreed to assist Russia in meeting its CWC obligations, construction is still proceeding in fits and starts on a destruction facility at Shchuch'ye to eliminate some 11,080 tons of nerve agent 
Threat Reduction and North Korea's CBW Programs

from two of Russia's five nerve agent storage sites. The United States currently expects to spend more than $\$ 1$ billion under the DOD Cooperative Threat Reduction (CTR) program for its share of the Shchuch'ye project and Russia another \$150-\$175 million. Russia and various international donors are to spend an additional \$187 million on infrastructure such as natural gas and water lines, an electric distribution station, rail lines and access roads, and sewage and fiber optic systems to support destruction operations. Once operational, Shchuch'ye is expected to destroy about 1,700 tons of nerve agent a year. ${ }^{46}$

Germany is helping to construct two additional destruction facilities-at Gorny and Kambarka-to dispose of Russia's stockpile of 7,480 tons of blister agent. In its first year of operation, the Gorny facility destroyed some 455 tons of agent. Once operational, the Kambarka facility will destroy an average of 1,600 tons per year. Germany has committed to provide up to $\$ 480$ million for these sites. ${ }^{47}$

Several times over the past decade, U.S. funding for Shchuch'ye has either been cancelled or suspended because of congressional concerns about the cost of the facility, the amount of Russian funding, the level of funding from other countries, the role of the facility in Russia's overall destruction program, or the status of the former Soviet offensive CW program. These interruptions have seriously affected both the construction schedule and the overall cost.

Fewer problems were encountered by UNSCOM in eliminating Iraq's more modest CW stockpile. Between June 1992 and May 1994, UNSCOM destroyed some 38,538 filled and unfilled munitions and 690 tons of CW agent. ${ }^{48}$ Unfilled and unstable filled munitions were destroyed in place using explosive charges in pits dug in the desert. All remaining filled munitions and bulk stocks were destroyed at Muthanna, Iraq's primary CW production site. Two specialized facilities were designed and constructed at Muthanna for this purpose: an incinerator for the destruction of mustard agent and a hydrolysis unit for neutralizing nerve agents. Empty munitions casings were cut up or crushed. Iraq constructed the destruction facilities - in some cases using equipment from its CW programand operated them under UNSCOM supervision. Some 100 specialists from 25 countries participated in the effort. ${ }^{49}$

Thus far, Libya's destruction of its even smaller CW stockpile has moved forward even more smoothly. Earlier this year, Libya accepted help from the United States and the United Kingdom in preparing its CWC declaration to the OPCW and quickly destroyed its unfilled chemical munitions under OPCW supervision. Although both the United States and the OPCW are providing technical advice, Libya is expected to eliminate its 23 tons of mustard agent itself, using either incineration or neutralization technology. ${ }^{50}$

A CW destruction plan for North Korea could draw from all of these experiences. North Korea would likely need at least two dedicated destruction facilities to destroy its CW stockpile, assuming it is between 2,500-5,000 tons of agent. These facilities could be located at one or more North Korean CW storage sites 
or CW production facilities. Equipment from the North Korean CW program might be able to be used in the destruction effort, including for environmental monitoring and other activities that support destruction operations. ${ }^{51}$ Unfilled munitions could be disposed of in a scrap metal facility. Technical and other assistance could be provided by the other participants in the Six-Party Talks (the United States, Russia, China, South Korea, and Japan), each of whom has had experience destroying chemical weapons. Provided that North Korea had acceded to the CWC, the OPCW could also provide technical advice on the destruction plan as well as oversee its implementation.

BW agents could be destroyed using steam autoclaves, which would have to be available in any North Korean BW facility. Empty munitions could be decontaminated and disposed of in a scrap metal facility along with unfilled chemical munitions. The United States and other former BW possessors, such as Russia and the United Kingdom, as well as countries with active biodefense programs, could provide technical advice to the North Koreans, including on how to ensure that no live agent remains at the end of the destruction process. Equipment used to monitor BW destruction could later be incorporated into civilian environmental monitoring activities.

\section{Infrastructure}

Under the CWC, parties are required to declare their CW development, production, and storage facilities and to destroy their production facilities unless they are to be converted for $\mathrm{CW}$ destruction or for other purposes permitted under the convention. Although the BTWC does not specifically address infrastructure, BW facilities have been dismantled under threat reduction programs in both the former Soviet Union and Iraq.

In recent years, DOD has begun to fund infrastructure-elimination activities at a variety of former Soviet CW facilities. In Uzbekistan, for example, all pilot plant reactors, vessels, and pipes at the Nukus CW facility have been dismantled, decontaminated, and removed to a sanitary landfill. Laboratory equipment, filtration systems, and ductwork from some 70 labs and rooms have also been demilitarized. After years of resistance, similar activities are now under way to convert two of Russia's former CW production facilities, at Volgograd and Novocheboksarsk, consistent with CWC requirements. ${ }^{52}$

DOD has also dismantled the world's largest anthrax production facility at Stepnogorsk in Kazakhstan and decontaminated a major BW test site on Vozrozhdeniye Island in Uzbekistan. Both projects required extensive sampling and analysis capabilities and environmental monitoring. Plans are now being developed to eliminate BW equipment at key Russian biological research and production facilities like Vector, Obolensk, Golitsino, and Pokrov. ${ }^{53}$ 
Threat Reduction and North Korea's CBW Programs

Even before facility dismantlement activities began in the former Soviet Union, UNSCOM had begun to eliminate Iraq's CW and BW production capabilities. Overall, UNSCOM destroyed 426 pieces of CW production equipment and 91 pieces of related analytical instruments, including reaction vessels, heat exchangers, distillation columns, and corrosion resistant fittings. Some CW production equipment was not destroyed until late 1997 because of Iraqi efforts to hide it. UNSCOM also surveyed and developed monitoring plans for various facilities-including chemical laboratories and pesticide, insecticide, fertilizer, petrochemical, leather tanning, military munitions, and heavy engineering plants- that could be used to support future CW activities. ${ }^{54}$

UNSCOM also oversaw the destruction of Al Hakam, Iraq's main BW production facility, after Iraq finally acknowledged that it had an offensive BW program. Buildings and equipment at the site were demolished using conventional explosives and the remnants buried. Equipment from two other BW facilities was also destroyed, and a high-containment air handling system was deactivated. ${ }^{55}$ UNSCOM also conducted baseline inspections and developed monitoring plans for 80 biological sites that could in the future be used for BW purposes, including laboratories (in hospitals, universities, and the food industry) and biological production facilities (single-cell protein, vaccine, drug formulation and production, as well as breweries and distilleries). Sites with agricultural crop sprayers were also included in UNSCOM's monitoring plans. ${ }^{56}$

Following the withdrawal of UN inspectors in December 1998 and again during the Second Gulf War, suspected Iraqi CW and BW facilities were priority targets. Since that time, companies that were part of Iraq's Military Industrialization Commission have been inspected and either closed, dispersed, or dismantled through privatization..$^{57}$

In contrast to Iraq, Libya has allowed U.S. and UK experts to visit any location and has provided complete access to its CW production facility at Rabta and other priority sites. Libya has decided to use Rabta to produce pharmaceuticals products, including low-cost HIV/AIDs drugs. Italy, which has close historical ties to Libya, plans to assist in the effort, which will be supervised by the OPCW. Rabta's reactor vessels, steel tanks, and other CW production equipment will be destroyed and physical security arrangements around the facility eliminated. Other equipment Libya was storing for a second CW production facility will also be destroyed. ${ }^{58}$

Decisions concerning the dismantlement of North Korea's dual-use CW and BW facilities would likely be influenced by a number of factors, including the actual number of facilities, their location, the existing activities at each site, and the type and size of equipment available for non-weapons purposes. ${ }^{59}$ As noted above, North Korea could temporarily convert one or more of its $\mathrm{CW}$ production facilities to $\mathrm{CW}$ destruction facilities. Depending on the political context in which 
threat reduction activities are being carried out, consideration also might be given to converting one or two of North Korea's dual-use CW or BW facilities from weapons activities to work on medical countermeasures and other defenses against chemical and biological weapons. However, any permitted defensive activities should be consolidated at as few sites as possible in order to avoid leaving in place a large weapons $R \& D$ and production capability. Other dual-use facilities could be converted to purely industrial, agricultural, research, medical, pharmaceutical, or other peaceful purposes. Although products from these facilities would not meet Western Good Laboratory or Manufacturing Practice (GLP or GMP) requirements, they would help boost North Korea's standard of living and could potentially be a source of export earnings through sales in other parts of Asia or the developing world.

BW and possibly CW equipment could be used for sampling and analysis, environmental monitoring, and other activities that support facility dismantlement activities-especially important in the case of any BW test site that needed to be decontaminated. Technical or other assistance for all of these activities could be provided by the other Six-Party Talks participants, each of whom has had experience dismantling or converting CW facilities and, in the case of the United States and Russia, BW facilities. Provided that North Korea accedes to the CWC, the OPCW could also provide technical advice on North Korea's facility destruction and conversion plans and could help ensure that its remaining chemical infrastructure is not used to develop or produce chemical weapons.

\section{Materials}

Large quantities of precursor chemicals are needed to produce CW agents. These generally dual-use chemicals (and the facilities where they are produced) are subject to various reporting and monitoring requirements under the CWC, depending on the toxicity of the chemicals or their role in the production of $\mathrm{CW}$ agents. By comparison, BW agent production involves much smaller quantities of seed stock that are available in many culture collections, diagnostic labs, and other facilities that work with dangerous pathogens. Moreover, although the BTWC prohibits the possession of agents and toxins "of types and in quantities that have no justification for prophylactic, protective or other peaceful purposes," there are no internationally agreed standards as to what this means, nor are there internationally agreed requirements for controlling access to such materials. Notwithstanding these problems, progress has been made in securing not only CW materials in all three countries but also BW materials in the former Soviet Union and Iraq.

In 1999, for example, the United States decided to bolster security at Russia's Shchuch'ye and Kizner CW storage sites by installing sensors, fences, lighting, closed circuit TV, and alarms. These sites were given priority attention because 
Threat Reduction and North Korea's CBW Programs

they contain nerve agent munitions that are light enough to be moved by individuals. The U.S. Congress provided $\$ 20$ million to DOD for this purpose. Security upgrades at these sites have gone relatively smoothly, perhaps in part because they had already been identified as CW storage locations. ${ }^{60}$

$\mathrm{DOD}$ is also funding projects aimed at preventing the theft, sale, diversion, or accidental release of pathogens at biological research and production facilities at Vector, Obolensk, Golitsino, and Pokrov in Russia; at Otar and Almaty in Kazakhstan; and at Tashkent and Samarkand in Uzbekistan. These biosafety and biosecurity efforts include education and training in safe storage and handling of pathogens, updated waste treatment and filtration systems, and physical security upgrades such as new fences, electronic sensors, guard facilities, and alarms. DOD is also helping to relocate pathogen collections at Soviet-era disease-tracking stations in Kazakhstan, Uzbekistan, and Georgia to secure, central repositories with modern surveillance, research, and communication capabilities, thus reducing the need for retaining dangerous pathogens at multiple locations. Some $\$ 124$ million is expected to be spent to design and construct four centralized labs for these countries. ${ }^{61}$

DOD officials reportedly believe, however, that biosafety and biosecurity upgrades may be needed at as many as 20 Russian facilities that were part of the former BW program. But Russia has been unwilling to provide access to or information about most of these sites, including their pathogen collections and security conditions. ${ }^{62}$ This lack of Russian cooperation has been exacerbated by periodic suspensions of new U.S. assistance because of concerns about Russia's compliance with its BW and CW arms control obligations.

Following the First Gulf War, UNSCOM destroyed more than 3,000 tons of precursor chemicals at Iraq's Muthanna CW production facility, using both incineration and hydrolysis units. UNSCOM also destroyed growth media that had been purchased by Saddam Hussein's government for its BW program. ${ }^{63}$ As noted above, however, Iraq never accounted for all of the CW and BW agent or related materials UNSCOM believed it possessed.

More recently, Libya reportedly has agreed, at the suggestion of U.S. and UK experts, to consolidate its mustard stockpile at a more secure location pending its elimination. The United States plans to work closely with Libya and the OPCW on plans for the destruction of its $\mathrm{CW}$ agent and precursor chemicals, the latter of which were said by U.S. officials to be for both mustard and nerve agent production. ${ }^{64}$

Some material security and elimination activities are likely to be necessary in North Korea, assuming it possesses a modest stockpile of chemical weapons. Depending on their condition, CW stocks may need to be consolidated and secured at fewer locations until a destruction plan can be designed and implemented. CW precursors could be redirected to civilian production-for example, for industrial or agricultural purposes. Technical and other assistance could be provided by other participants in the Six-Party Talks, all of whom possess precur- 
sor chemicals controlled under the CWC. Additional technical assistance and monitoring resources would also be available from the OPCW if North Korea were to become a party to the CWC.

Dangerous pathogens used in North Korea's BW program or that might be available in culture collections, disease tracking stations, or diagnostic labs should be consolidated and secured in order to prevent unauthorized access. Particular attention should be given to creating a reference library with modern research and communications capabilities to help bolster North Korea's public health system. This should be accompanied by a robust biosafety and biosecurity program, involving everything from training in the safe handling of pathogens to physical security upgrades.

\section{Personnel}

As one U.S. official has pointed out, redirecting former CW and BW experts is in many ways the most important threat reduction task, as the knowledge of how to develop and produce CW and BW agents is essential to a successful weapons program. ${ }^{65}$ It is also potentially the hardest to control, particularly as closed and less-developed societies begin to open to the outside world, thus increasing the risk that weapons experts will use their knowledge to secure a better life outside their country of origin. Nowhere was this more true than in the former Soviet Union following the end of the Cold War.

Over the past decade, the United States has sponsored a range of programs aimed at engaging former Soviet CW and BW experts in legitimate activities and preventing a potential "brain drain" to rogue states or terrorists groups. The U.S. Department of State has been the lead player in these efforts. Under its scientist redirection program, State has provided some $\$ 85$ million to the Department of Health and Human Services, the Department of Agriculture, and the Environmental Protection Agency for collaborative research with former BW scientists on issues such as global public health; livestock and plant health; environmental monitoring and remediation; and $\mathrm{CW}$ and $\mathrm{BW}$ counterterrorism measures. ${ }^{66}$ State is also partnering with U.S. industry to engage former BW production facility personnel in peaceful activities such as vaccine and drug development. As part of this bioindustry initiative, State is providing assistance in developing business plans, conducting market research, meeting international GLP/GMP standards, identifying commercial partners and venture capital, and accelerating drug and vaccine development, especially against dangerous pathogens. ${ }^{67}$ A similar proliferation prevention program, sponsored by the Department of Energy, focuses on redirecting former BW experts toward commercially viable activities in partnership with the U.S. national laboratories and U.S. industry. 
Threat Reduction and North Korea's CBW Programs

DOD has also been involved in redirecting former Soviet CW and BW experts, including by funding research projects in Central Asia and the Caucuses focused on strengthening national and international disease surveillance and response capabilities. It has also funded collaborative research projects on medical defenses against biological weapons at eight former BW research and production facilities in Kazakhstan, Uzbekistan, and Russia and helped establish an analytical laboratory for the Russian $\mathrm{CW}$ destruction program at a former $\mathrm{CW}$ research institute in Moscow. ${ }^{68}$

Since the beginning, the U.S. government has recognized that keeping former weapons experts in place at the very institutes that had played a key role in the Soviet BW program, in particular, posed potential risks. But the sheer number of facilities and personnel involved, as well as other factors inherent in the Sovietera social structure (such as personal health insurance being tied to one's place of employment rather than a national system) effectively precluded any other approach. The United States has tried to mitigate these risks in a variety of ways, including by seeking assurances from both the relevant facilities and individual scientists that they will not engage in proliferation or BW activities. The United States has also required that all potential research projects be carefully reviewed, not only for scientific merit but also for dual-use potential. And it has tried to ensure that any collaborative research activities that it funds are subject to rigorous financial and programmatic oversight. ${ }^{69}$

A different approach is being used to deal with the much smaller number of experts that helped develop and produce Iraq's weapons of mass destruction. Instead of being kept in place, weapons experts are being transferred to other positions where they can use their skills to contribute to Iraq's economic development and reconstruction. This effort is expected to be supported by the Iraqi Nonproliferation Program Foundation (INPF), which was established by the Coalition Provisional Authority in June 2004 to help redirect former weapons experts to peaceful civilian activities. The INPF has the authority to fund a variety of opportunities for former weapons experts, including consulting jobs and other employment, retraining programs, travel, outreach and education programs, product development and commercialization, and a venture capital fund. Thirty-five million dollars was transferred from the Development Fund for Iraq to support the INPF's initial two years of work. ${ }^{70}$

The State Department has also launched a program to redirect Iraq's former weapons experts, the centerpiece of which is the creation of an Iraqi International Center for Science and Industry. Under the Iraqi science center, former weapons scientists are being hired as technical consultants to Iraq's science and technology, health, education, agriculture, environment, and utility ministries. Already some 60 scientists of an estimated 500 top WMD scientists have been employed on a short-term basis. ${ }^{71}$ 
State is also funding four other Iraqi science center activities. The first is a series of workshops, each of which will involve 100 former weapons experts and will focus on one of Iraq's key reconstruction priorities: energy research, environmental protection, information technology, agriculture, chemical research and production, and industrial development. The second activity will provide between 150-300 former weapons experts with technical training in areas like desalination; air, water, and soil sampling; and modern university science curricula. The third activity will use scientist-to-scientist meetings around the country to identify those individuals with weapons-relevant expertise who should be included in future redirection projects. The final activity will train Iraqi scientists to participate in a desalination demonstration project aimed at helping meet Iraq's long-term water needs. The Iraqi science center's work is being overseen by a Science Advisory Council composed of 14 scientists from diverse fields, 11 of whom have WMD backgrounds. ${ }^{72}$ Two million dollars has been allocated from State's Nonproliferation and Disarmament Fund for the science center's initial activities. ${ }^{73}$

The Energy Department has also begun a program together with Sandia National Laboratories and the Arab Science \& Technology Foundation to develop new employment opportunities for Iraqi weapons experts and to revitalize Iraq's broader science and technology (S\&T) community. Under this program, a survey is being conducted of Iraq's S\&T infrastructure. This survey is to be followed by a workshop in the United Arab Emirates to discuss reconstruction priorities and options for technical cooperation. These initial activities are expected to cost approximately $\$ 500,000$. Funding for actual projects will be sought from other countries and organizations. ${ }^{74}$

Given that its weapons expert community is even smaller than that of Iraq, Libya will likely follow the Iraqi redirection model, though on a much more limited scale. ${ }^{75}$ North Korea could combine elements of both the former Soviet and Iraqi models, depending on the expertise and size of the community that has been involved in its CW and BW activities. In the short term, support personnel from North Korea's CW program could be used, for example, to help build new roads or other infrastructure needed for CW destruction or to help dismantle former CW facilities. Scientists and others from the CW program with more technical backgrounds could conduct environmental monitoring and other activities necessary for the safe elimination of $\mathrm{CW}$ and related facilities. Former BW scientists and technicians could be used for similar activities, including overseeing the destruction of any existing BW agents and environmental testing at former BW facilities that are being decontaminated or dismantled. If a limited CW or BW defense effort is maintained, this work could also be undertaken by scientists from the former offensive programs. Such defensive work would need, however, to be done openly and under monitoring arrangements that provided confidence that it was not being misused for offensive purposes. The same would be true for any advanced research in inherently dual-use areas like biotechnol- 
Threat Reduction and North Korea's CBW Programs

ogy. Consideration might in fact be given to co-locating both advanced research and any $\mathrm{CW}$ and $\mathrm{BW}$ defense work. At a minimum, nonproliferation assurances should be sought from experts working in these areas.

Clearly, the bulk of North Korea's CW and BW experts should be redirected to permanent, peaceful activities that help address some of the country's most urgent industrial, agricultural, research, medical, and pharmaceutical needs. North Korean CW experts could, for example, play an important role in helping reverse more than a decade of famine conditions by developing and producing fertilizers to enhance crop yield and microorganisms for pest control. Former BW scientists could also make single cell proteins and drugs for healthier livestock and bolster public health by producing chemicals to sanitize water supplies and drugs to treat waterborne diseases like cholera and infectious diseases like tuberculosis and hepatitis-C. They could also play a role in disease surveillance programs and work in diagnostic laboratories and hospitals. Finally, North Korea's $\mathrm{CW}$ and BW experts could contribute to institution building by serving as technical consultants to civilian ministries responsible for agriculture, science, health, the environment, and utilities, and by taking positions in universities and other academic centers.

\section{Conclusions}

CW and BW threat reduction activities in the former Soviet Union, Iraq, and Libya provide a menu of program ideas of potential relevance to North Korea. But there are also a number of important lessons to be learned from the actual experience with threat reduction in these countries. ${ }^{76}$ Admittedly, in the current political climate, the possibility of engaging in threat reduction efforts in North Korea appears to be remote. Nevertheless, it is useful to begin to think not only about what specific threat reduction activities might be relevant to Pyongyang's CW and BW programs but also about how one might incorporate such activities in a negotiated settlement with North Korea or any other country of proliferation concern.

First, threat reduction activities should be linked to international nonproliferation regimes. As was done recently with Libya, North Korea should be required to reaffirm its commitment to the BTWC, which it has been a party to since 1982, and to join the CWC. In return, the United States and other countries should undertake a formal commitment to assist North Korea in meeting its longstanding BTWC and new CWC obligations. The United States and international community would thus have clear benchmarks against which to measure North Korea's CW and BW disarmament efforts and, in the case of CW, actual monitoring assistance from the OPCW. For its part, North Korea would obtain tangible benefits from the outset for agreeing to forego the development and possession of $\mathrm{CW}$ and $\mathrm{BW}$. 
Second, threat reduction activities should be pursued with multilateral partners. Many of the U.S. programs to redirect former Soviet CW and BW scientists have been undertaken in conjunction with the International Science and Technology Center (ISTC), whose membership includes the European Union, Canada, Norway, South Korea, and Japan. This cooperation has helped provide broader financial support for threat reduction in the former Soviet Union. Multilateral partners can also bring much-needed political support to threat reduction efforts, as was evident during the UN's disarmament work in Iraq during the 1990s.

Various multilateral partners could play a role in threat reduction activities in North Korea. Clearly, the countries participating with North Korea in the SixParty Talks should be at the center of these efforts. All of them, with the exception of China, have been involved in the ISTC's threat reduction activities and, as discussed above, most have had BW and/or CW programs and thus have had experience in destroying both weapons and related facilities. South Korea would play an especially important role, given its unique cultural, language, and other ties. The European Union and other G-8 Global Partnership members could also be involved, having recently reaffirmed their support for addressing proliferation challenges worldwide, including reinforcing biosecurity. ${ }^{77}$ This involvement would bring together the G-8 and more than a dozen other donor countries. ${ }^{78}$

Third, threat reduction activities should be subject to strong oversightespecially important in the $\mathrm{CW}$ and $\mathrm{BW}$ areas, given the dual-use nature of many of the facilities and materials involved. As in Russia and Libya, the OPCW should have the primary responsibility for ensuring that only permitted activities are under way at North Korea's chemical facilities. However, in the absence of a BTWC inspection arrangement, the United States and other members of the international community will have to rely on audits, periodic visits, reporting, and other oversight tools developed for the former Soviet Union to prevent North Korea's biological facilities from being used for illicit purposes.

Fourth, threat reduction programs ultimately should be self-supporting. Although the United States and other members of the international community continue to play a critical role in threat reduction activities in the former Soviet Union, responsibility for eliminating the former Soviet CW and BW programs clearly resides with Russia and its fellow former Soviet countries. Outside assistance, especially at the outset, can help give threat reduction efforts an impetus. But eventually, former weapons facilities and personnel must be capable of functioning on their own. For Russia, this means focusing on commercialization opportunities. For countries like Iraq and Libya, which are trying to recover from the debilitating effects of years of economic sanctions, reconstruction and economic development are the priorities. The same would be true of North Korea.

Finally, threat reduction activities should be based on realistic expectations. More than a decade of threat reduction experience in the former Soviet Union and Iraq suggests that threat reduction programs are exactly that - a means of 
Threat Reduction and North Korea's CBW Programs

reducing, but not necessarily eliminating, the threat from foreign $\mathrm{CW}$ or $\mathrm{BW}$ programs. Even with complete cooperation, as is apparently the case in Libya, it may be difficult to reconcile a country's disclosures regarding its weapons programs and prevailing intelligence assessments. Donor countries may well have to accept, therefore, that the elimination of $\mathrm{CW}$ or $\mathrm{BW}$ programs may take longer than expected, or may leave some issues unresolved. But even incremental progress toward eliminating the threat from CW and BW programs in North Korea and other countries is a goal worth achieving.

This article is based on a working paper prepared for a project on threat reduction and North Korea's weapons of mass destruction sponsored by the Carnegie Endowment for International Peace and the Center for Strategic and International Studies. The author is grateful to Anne Harrington and Milton Leitenberg for their very thoughtful comments on an earlier draft and to Daniel Pinkston for providing copies of some of the South Korean source materials.

${ }^{1}$ For a more detailed discussion, see International Institute for Strategic Studies, North Korea's Weapon Programmes: A Net Assessment (London: Palgrave Macmillan, 2004), pp. 49-62.

${ }^{2}$ U.S. Department of Defense (DOD), Proliferation: Threat and Response (Washington DC: U.S. Government Printing Office, April 1996), p. 7. Other U.S. government reports describe the program simply as "longstanding." See Message from the President of the United States, Emergency Regarding Proliferation of Weapons of Mass Destruction, House Document 108-41 (Executive Order 12938 Report), 108th Cong., 1st sess., February 26, 2003, pp. 13-14; and Central Intelligence Agency (CIA), Unclassified Report to Congress on the Acquisition of Technology Relating to Weapons of Mass Destruction and Advanced Convention Munitions, 1 January Through 30 June 2002, (CIA Section 721 Report).

${ }^{3}$ DOD, Proliferation: Threat and Response, April 1996, p. 7; President of the United States, Emergency Regarding Proliferation of Weapons of Mass Destruction, p. 14. It is not clear what the phrase "capable of producing" means. Is it intended, for example, to distinguish between technical ability and actual production of agent?; CIA, Unclassified Report to Congress, 1 January Through 30 June 2002; DOD, Proliferation: Threat and Response (Washington DC: U.S. Government Printing Office, January 2001), p. 11.

${ }^{4}$ U.S. Senate, Armed Services Committee, Statement of General Thomas A. Schwartz, Commander in Chief United Nations Command/Combined Forces Command \& Commander, United States Forces Korea, 107th Cong., 2nd sess., March 2002, p. 8.

${ }^{5}$ CIA, Unclassified Report to Congress on the Acquisition of Technology Relating to Weapons of Mass Destruction and Advanced Convention Munitions, 1 January Through 30 June 2001; John R. Bolton, Under Secretary of State for Arms Control and International Security, U.S. Department of State, "The International Aspects of Terrorism and Weapons of Mass Destruction," remarks at the Hudson Institute, November 1, 2002.

${ }^{6}$ The 5,000 metric tons comes from a USFK J-2 briefing in August 2000. See Stephen Bradner, "North Korea's Strategy," paper presented at the third NPEC/Institute for National Security Studies/Army War College-sponsored workshop on Comparative Strategies, Arlington, Virginia, June 12-14, 2000, <http:// www.nti.org/db/profiles/dprk/chem/chron/NKC_CH97to00GO_bg.html>. The 2,500 figure was reported by John Bolton in a speech in Seoul in August 2002. See John R. Bolton, Under Secretary of State for Arms Control and International Security, U.S. Department of State, "North Korea: A Shared Challenge to the U.S. and the ROK," remarks in Seoul, August 29, 2002.

${ }^{7}$ In typical Russian fashion, it does this by referring to "military-applied work in the chemical sphere and to an adequate industrial base." See Russian Foreign Intelligence Service (FSB), A New Challenge after the "Cold War": The Proliferation of Weapons of Mass Destruction (Moscow: 1993), p. 61.

${ }^{8}$ At the same time, the report quoted North Korea's 1993 denial that it possessed CW. See Russian FSB, A New Challenge after the "Cold War," p. 61. 


\section{ELISA D. HARRIS}

${ }^{9}$ ROK Ministry of National Defense (MND), Defense White Paper 2000.

${ }^{10}$ ROK MND Defense White Paper 2001; ROK MND, Handbook on Weapons of Mass Destruction, December 10, 2001, in FBIS document KPP20020103000062.

${ }^{11}$ It is assumed that the South Korean figures are for agent tons, even though some sources refer to "weapons."

${ }^{12}$ ROK MND Defense White Paper 1993-94.

${ }^{13}$ ROK MND Defense White Paper 1996.

${ }^{14}$ ROK MND Defense White Paper 2001. It is not clear whether other ROK defense white papers have addressed this issue since that time.

${ }^{15}$ Joseph Bermudez, "Inside North Korea's CW Infrastructure," Jane's Intelligence Review 8 (August 1996), p. 380. These are more CW agents than were produced by either the United States or the former Soviet Union. ${ }^{16}$ Pak Tong-sam, "How Far Has the DPRK's Development of Strategic Weapons Come?" Pukhan, January 1, 1999, pp. $62-71$ in FBIS document FTS19990121001655. This article also included diphosgene, cyanogen chloride, DA, and BZ; Kyoung-Soo Kim, "North Korea's CB Weapons: Threat and Capability," The Korean Journal of Defense Analysis XIV (Spring 2002), p. 84. Although the article cited the Pukhan article as its source, the actual list was identical to the 1996 Bermudez list.

17 "Defense Minister on DPRK Submarine, Rocket Test," The Korea Herald, January 29, 1987, p. 1, <http:/ /www.nti.org/db/profiles/dprk/chem/chron/NKC_CH47to96GO_bg.html>.

${ }^{18}$ Joseph Bermudez, "North Korea's Chemical and Biological Warfare Arsenal," Jane's Intelligence Review 5 (May 1993), p. 228.

${ }^{19}$ Pak Tong-sam, "How Far Has the DPRK's Development of Strategic Weapons Come?"

${ }^{20}$ See, for example, the claims of defector Yi Ch'un-son as reported in Ch'oe Yong-chae, "U.S. Strategy Pressuring DPRK on Biological, Chemical Weapons Issue," Sindong-a, January 1, 2002, pp. 300-313, in FBIS document KPP20011220000016; and U.S. Senate, Governmental Affairs Committee, prepared statement of Choi Ju-hwal, Former Official, Ministry of the People's Army, October 21, 1997.

${ }^{21}$ See, for example, Bermudez, "North Korea's Chemical and Biological Warfare Arsenal," p. 228; U Chongchang, Chugan Choson, June 30, 1994, pp. 26-28, in FBIS document EAS-94-126, June 30, 1994, p. 38; Bermudez, "Inside North Korea's CW Infrastructure," p. 381; U.S. Senate, statement of Choi Ju-hwal, October 21, 1997; Joseph Bermudez, Case Study \#5: North Korea (Chemical and Biological Arms Control Institute [CBACI], 1998), pp. 6-8; Pak Tong-sam, "How Far Has the DPRK's Development of Strategic Weapons Come?"; and Kyoung-Soo Kim, "North Korea's CB Weapons," pp. 73-76.

${ }^{22}$ The February 2003 Executive Order 12938 report, for example, refers to a "dedicated, national leveleffort to achieve" a BW capability. See President of the United States, Emergency Regarding Proliferation of Weapons of Mass Destruction, p. 13. See also CIA, Unclassified Report to Congress, 1 January Through 30 June 2002.

${ }^{23}$ In testimony in March 2002, INR Assistant Secretary of State Carl Ford described it as "basic." See U.S. Senate, Committee on Foreign Relations, Hearing on Reducing the Threat of Chemical and Biological Weapons, statement of Carl W. Ford, Jr., Assistant Secretary of State for Intelligence and Research, March 19, 2002. The 2001 Proliferation: Threat and Response report and 2000 Noncompliance report both described it as "rudimentary." See DOD, Proliferation: Threat and Response, January 2001, p. 10; and U.S. Department of State, "Annual Report to Congress 2000: State Department Report on Activities in Arms Control, Nonproliferation, and Disarmament," p. 43.

${ }^{24}$ The usual formulation has been that North Korea "may have" biological weapons. See CIA, Unclassified Report to Congress, 1 January Through 30 June 2002; President of the United States, Emergency Regarding Proliferation of Weapons of Mass Destruction; and Bolton, "North Korea: A Shared Challenge to the U.S. and the ROK."

${ }^{25}$ DOD, Proliferation: Threat and Response, January 2001, p. 10; and Bradner, "North Korea's Strategy." ${ }^{26}$ More specifically, the report said: "Information on the offensive nature of these programs has not been received." Russian FSB, A New Challenge after the "Cold War," p. 62.

${ }^{27}$ ROK MND Defense White Paper 1998; and ROK MND Defense White Paper 1999.

${ }^{28}$ ROK MND, Handbook on Weapons of Mass Destruction; ROK MND Defense White Paper 2001

${ }^{29}$ The map is reproduced at $<$ http://www.nti.org/e_research/profiles/NK/Biological/index.html $>$. 


\section{Threat Reduction and North Korea's CBW Programs}

${ }^{30}$ See, for example, ROK MND Defense White Paper 1999; and ROK MND Defense White Paper 2000.

31 "Pukhan Saenghua Hangmugi Shilch'onbaech'i/Angibu Kukkambogo" ("North Korea Operationally Deploys Bio-chemical Weapons"), Segye Ilbo, October 24, 1992, < http://www.nti.org/db/profiles/dprk/bio/ chron/NKB CHGO bg.html>.

${ }^{32}$ See Kang Tong-hyong, "Status of North Korea's Arsenal of Weapons of Mass Destruction," Taehan Maeil, November 28, 2001, in FBIS document KPP20011127000106; "DPRK Biological Research Institute's Developments in 'Germ Weapons' Detailed," Choson Ilbo, December 3, 2001, in FBIS document KPP20011203000106; and Jong-Heon Lee, "North Korea Amasses Chemical Weapons," Washington Times, September 17, 2002.

${ }^{33}$ Bermudez, Case Study \#5: North Korea, p. 12.

${ }^{34}$ Kyoung-Soo Kim, "North Korea's CB Weapons," p. 84.

${ }^{35}$ See, for example, Ibid., pp. 81-82; "DPRK Biological Research Institute's Developments in 'Germ Weapons' Detailed"; Pak Tong-sam, "How Far Has the DPRK's Development of Strategic Weapons Come?”; Yi Chae-sung, "Pukhanul Umjiginum T'ek'unok'uratu," August 25, 1998, pp. 180-97, in FBIS document FTS19991006001519; U.S. Senate, statement of Choi Ju-hwal, October 21, 1997; U Chongchang, Chugan Choson, June 30, 1994; and "Pukhan Saenghua Hangmugi Shilch'onbaech'i/Angibu Kukkambogo" ("North Korea Operationally Deploys Bio-chemical Weapons"), Segye Ilbo, October 24, 1992.

${ }^{36}$ See, for example, U.S. Department of State, "Adherence to and Compliance with Arms Control Agreements and Nonproliferation Agreements and Commitments," December 1, 2000-December 31, 2001, p. 11; Russian FSB, A New Challenge after the "Cold War," pp. 63-64; and DOD, Proliferation: Threat and Response, 1996, pp. 26-27.

${ }^{37}$ DOD, News Transcript, "News Briefing - Secretary Rumsfeld and Gen. Myers," June 24, 2003, < http:/ /www.defenselink.mil/transcripts/2003/tr20030624-secdef0301.html>.

${ }^{38}$ Organization for the Prohibition of Chemical Weapons (OPCW), Press Release, March 22. 2004, "Initial Inspection in Libya Completed."

${ }^{39}$ White House, Office of the Press Secretary, "Press Background Briefing by Senior Administration Officials," December 19, 2003, < http://www.un.org/Depts./unscom/s99-94.htm>.

${ }^{40}$ United Nations, Letter dated 27 January 1999 from the Permanent Representatives of the Netherlands and Slovenia to the United Nations Addressed to the President of the Security Council, UN Document S/1999/94, January 29, 1999.

${ }^{41}$ United Nations, "Unresolved Disarmament Issues: Iraq's Proscribed Weapons Programmes," March 6, 2003, in United Nations Monitoring and Verification Commission, Draft Work Programme, March 17, 2003, <http://www.un.org/Depts/unmovic/new/documents/draft_work_programme.pdf> .

${ }^{42}$ See, for example, Gary Hart, "My Secret Talks with Libya, and Why They Went Nowhere," Washington Post, January 18, 2004; and Martin S. Indyk, "The Iraq War Did Not Force Gadaffi's Hand," Financial Times, March 9, 2004.

${ }^{43}$ White House, Office of the Press Secretary, "Press Background Briefing by Senior Administration Officials," December 19, 2003; John R. Bolton, Under Secretary of State for Arms Control and International Security, "Lessons from Libya and North Korea's Strategic Choice," remarks in Seoul, July 21, 2004.

${ }^{44}$ Robin Wright, "U.S. Opens Libya Interest Section, Plans Other Steps," Washington Post, February 11, 2004; White House, Office of the Press Secretary, Statement by the Press Secretary, "U.S. Eases Economic Embargo Against Libya," April 23, 2004.

${ }^{45}$ United Nations, S/1999/94.

${ }^{46}$ U.S. General Accounting Office (GAO), "Delays in Implementing the Chemical Weapons Convention Raise Concerns About Proliferation," GAO-04-361, March 2004, pp. 20-22, 34, 37.

${ }^{47}$ Ibid., pp. 20-21.

${ }^{48}$ United Nations Special Commission, "UNSCOM Main Achievements," March 1998, <http:// www.un.org/Depts/unscom/Achievements/achievements.html> .

${ }^{49}$ United Nations, Note by the Secretary General, UN document S/1996/848, October 11, 1996.

${ }^{50}$ OPCW, “Initial Inspection in Libya Completed”; U.S. House of Representatives, International Relations Committee, Weapons of Mass Destruction, Terrorism, Human Rights and the Future of U.S.-Libyan Relations, testimony of Paula A. DeSutter, Assistant Secretary of State for Verification and Compliance, March 10, 


\section{ELISA D. HARRIS}

2004; Chris Schneidmiller, "Experts Say Much Work Needed to Finish Libyan Disarmament," Global Security Newswire, March 23, 2004.

${ }^{51}$ The CWC has strict rules concerning the types of equipment that can be retained.

${ }^{52}$ See, for example, Defense Threat Reduction Agency (DTRA), "Nukus Chemical Research Institute Demilitarization," < http://www.dtra.mil/ctr/project/projuzb/ctr_nukus.html > (accessed on June 15, 2004); and DTRA, "Chemical Weapons Production Facilities Demilitarization," < http://www.dtra.mil/ctr/ project/projrus/ctr_cw_prod_delimil.html > (accessed on June 15, 2004).

${ }^{53}$ DTRA, "BW Production Facility Dismantlement," < http://www.dtra.mil/ctr/project/projkaz/ bw_prod_facil_disman.html> (accessed on June 15, 2004); DTRA, "VOZ ISLAND Biological Test Facility Aral Sea Region, Uzbekistan," < http://www.dtra.mil/ctr/project/projuzb/ctr_voz_island.html > (accessed on June 15, 2004); and DTRA, "Biological Weapons Proliferation Prevention Dismantlement," < http:// www.dtra.mil/ctr/project/projrus/ctr_bw_facility_disman.html> (accessed on June 15, 2004).

${ }^{54}$ United Nations, "UNSCOM Main Achievements," < http://www.un.org/Depts/unscom/Achievements/ achievements.html >; United Nations, S/1995/284, April 10, 1995.

${ }^{55}$ United Nations, S/1996/848, October 11, 1996.

${ }^{56}$ United Nations, S/1995/284, April 10, 1995.

${ }^{57}$ Anne Harrington, Office of Proliferation Threat Reduction, Department of State, interview with author, Washington, DC, May 2004.

${ }^{58}$ U.S. House of Representatives, testimony of Paula A. De Sutter; Schneidmiller, "Experts Say Much Work Needed to Finish Libyan Disarmament"; White House, Office of the Press Secretary, "Press Background Briefing by Senior Administration Officials," December 19, 2003; Michael Nguyen, "Chemical Weapons Body Recommends Extending Destruction Deadline for Libya, Albania," Arms Control Today News Update, July 22, 2004, < http://www.armscontrol.org/aca/midmonth/2004/JulyAugust/chem.asp>; Bolton, "Lessons from Libya and North Korea's Strategic Choice."

${ }^{59}$ The BW conversion issue is discussed in more detail in Milton Leitenberg, "The conversion of biological warfare research and development facilities to peaceful uses," in Erhard Geissler and John P. Woodall, eds., Control of Dual-Use Threat Agents: The Vaccines for Peace Programme, SIPRI Chemical and Biological Warfare Studies \#15 (Oxford University Press: Oxford, 1994), pp. 77-105.

${ }^{60}$ U.S. GAO, "Additional Russian Cooperation Needed to Facilitate U.S. Efforts to Improve Security at Russian Sites," GAO-03-482, March 2003, pp. 61-62.

${ }^{61}$ See, DTRA, "Biological Weapons Proliferation Prevention Security Enhancements," < http:// www.dtra.mil/ctr/project/projrus/ctr_bio_weap_sec_enh.html> (accessed on June 15, 2004); DTRA, "BW Materials Security and Transparency," < http://www.dtra.mil/ctr/project/projkaz/bw_secure_trans_html> (accessed on June 15, 2004); DTRA, "Samarkand Institute of Veterinary Science," < http://www.dtra.mil/ ctr/project/projuzb/ctr_samarkand.html> (accessed on June 15, 2004); DTRA, "Center for Prophylaxis and Quarantine of Most Hazardous Infections (CPQHI)," < http://www.dtra.mil/ctr/project/projuzb/ ctr_prop.html> (accessed on June 15, 2004); Michael Balady, "Countering the Legacy: Cooperative Threat Reduction and the Soviet Biological Weapons Program," PowerPoint presentation given at the Wilton Park Rose-Roth Seminar, United Kingdom, June 5-8, 2003 ; Linda Johnson, "Monitored Labs in Asian Republics Will Soon Store Biohazards," Associated Press, July 19, 2004

${ }^{62} \mathrm{GAO}-03-482$, pp. 44, 48 .

${ }^{63}$ United Nations, "UNSCOM Main Achievements"; UN S/1996/848.

${ }^{64}$ White House, "Press Background Briefing by Senior Administration Officials," December 19, 2003; U.S. House of Representatives, testimony of Paula A. De Sutter.

${ }^{65}$ Anne Harrington, "Cooperative Threat Reduction and North Korea: Learning from Russia, Iraq and Libya; Redirecting WMD/Missile Scientists," PowerPoint presentation given at the Center for Strategic and International Studies, Washington, DC, May 3, 2004.

${ }^{66}$ This figure covers activities through FY 2004. See U.S. Department of State, Bureau of Nonproliferation, Fact Sheet, "The U.S. Bio-Chem Redirect Program," May 12, 2004.

${ }^{67}$ Anne Harrington, presentation at the Center for International and Security Studies at Maryland, May 6 , 2004. Congress initially provided $\$ 30$ million for this program. See U.S. Department of State, Bureau of Nonproliferation, Fact Sheet, "Bioindustry Initiative," September 16, 2003. 


\section{Threat Reduction and North Korea's CBW Programs}

${ }^{68}$ Balady, "Countering the Legacy."

${ }^{69}$ U.S. GAO, "Effort to Reduce Former Soviet Threat Offers Benefits, Poses New Risks," GAO/NSIAD. 00-138, April 2000, pp. 6, 31-33; U.S. Senate, Armed Services Committee, testimony of Lisa Bronson, Deputy Under Secretary of Defense for Technology Security Policy and Counterproliferation, March 10, 2004. ${ }^{70}$ Coalition Provisional Authority Order Number 79, "The Iraqi Nonproliferation Program Foundation," June 19, 2004, < http://www.iraqcoalition.org/regulations/\#Orders>.

${ }^{71}$ Farah Stockman, "U.S. Offering Scientists from Iraq New Jobs," Boston Globe, July 16, 2004.

${ }^{72}$ U.S. Department of State, Office of the Spokesman, Fact Sheet, "Redirection of Iraqi Weapons of Mass Destruction (WMD) Experts Short-term Program," December 18, 2003; Harrington, interview by author. ${ }^{73}$ Stockman, "U.S. Offering Scientists from Iraq New Jobs."

${ }^{74}$ U.S. Department of Energy, National Nuclear Security Administration, "NNSA Program to Engage Iraqi Scientists," February 25, 2004; Michael Roston, "Redirection of WMD Scientists in Iraq and Libya: A Status Report," RANSAC Policy Update, April 2004, pp. 5-6.

${ }^{75}$ Libya's CW program, for example, relied much more on procurement from abroad than on indigenous research. As a consequence, it has more technicians than weapons scientists. The United States has indicated that it is developing ways of redirecting Libya's weapons experts to productive civilian pursuits. See U.S. House of Representatives, testimony of Paula A. De Sutter.

${ }^{76}$ This section has benefited from extensive discussion with Anne Harrington from the Department of State; Harrington, interview by author.

77 "G-8 Action Plan on Nonproliferation," Sea Island, Georgia, June 2004, <http://www.g8usa.gov/ d 060904d.htm>.

${ }^{78}$ Six countries became donors in 2003: Finland, the Netherlands, Norway, Poland, Sweden, and Switzerland. In 2004, they were joined by Australia, Belgium, the Czech Republic, Denmark, Ireland, New Zealand, and South Korea. 